Original Research Paper

\title{
Phytoremedial Potential of Tagetes Erecta Under Mycorrhizal Inoculation in Heavy Metal Polluted Soil
}

\author{
${ }^{1}$ Aina, I.O., ${ }^{2}$ Amusa, F.L., ${ }^{3}$ Olasupo, A.D., ${ }^{4}$ Olagoke, O.V. and ${ }^{5}$ Awodiran, T.P. \\ ${ }^{1}$ Institute of Ecology and Environmental Studies, Obafemi Awolowo, University, Ile-Ife, Nigeria \\ ${ }^{2}$ Department of Pure and Applied Chemistry, Ladoke Akintola University of Technology, \\ P.M.B 4000, Ogbomoso, Oyo State. Nigeria \\ ${ }^{3}$ Department of Industrial Chemistry, Federal University, Oye-Ekiti, Nigeria \\ ${ }^{4}$ Department of Microbiology, Obafemi Awolowo, University, Ile-Ife, Nigeria \\ ${ }_{5}^{5}$ Department of Pure and Applied Biology, Ladoke Akintola University of Technology, \\ P.M.B 4000, Ogbomoso, Oyo State. Nigeria
}

Article history

Received: 20-04-2019

Revised: 03-07-2019

Accepted: 26-10-2019

Corresponding Author:

Aina, I.O.

Institute of Ecology and

Environmental Studies,

Obafemi Awolowo, University,

Ile-Ife, Nigeria

Email:

ibukunoluwaomotoso6@gmail. com

\begin{abstract}
Investigation of the growth of Tagetes erecta under different levels of contamination of Copper $(\mathrm{Cu})$ and Lead $(\mathrm{Pb})$ in the soil and effects of mycorrhizal species (Glomus mosseae) on $\mathrm{Cu}$ and $\mathrm{Pb}$ to identify hyperaccumulator plants in tropical environment that could be used in remediation of heavy metal from contaminated soils. It was a greenhouse experiment consisted of factorial combination of two heavy metal $(\mathrm{Cu}$ and $\mathrm{Pb})$ treatments which were replicated three times in Complete Ramdomized Design (CRD) with two mycorrhizal (Glomus mosseae and non-mycorrhizal) treatments. Metal solutions of $\mathrm{Cu}$ and $\mathrm{Pb}$ at the concentrations of $\mathrm{Cu}$ are 0,125 , $250,500,1000 \mathrm{mg} \mathrm{kg}^{-1}$ and concentrations of $\mathrm{Pb}$ are $0,25,50,75,100 \mathrm{mg} \mathrm{kg}^{-1}$ were prepared using $\mathrm{CuCl}_{2}$ and $\mathrm{PbCl}_{2}$ soluble compounds respectively. Soil mycorrhizal inocula of Glomus mosseae was applied at the rate of $20 \mathrm{~g}$ per pot. Five seeds of Tagetes erecta were planted per pot and were thinned to two stands per pot at two weeks after planting. Pre- and post- soil tests were carried out to determine soil physical and chemical properties, using standard methods. At 12 Weeks After Planting (WAP), Tagetes erecta was harvested and analyzed for Copper and Lead uptake using Atomic Absorption Spectrophotometer. The data collected were analyzed using descriptive and inferential statistics. The results showed that Arbuscular Mycorrhizal Fungi enhanced the number of leaves, height and stem girth of Tagetes erecta in high concentration (1000 mg $\mathrm{kg}^{-1}$ ) of $\mathrm{Cu}$ contaminated soil. Glomus mosseae inoculation did not enhance the growth parameters of Tagetes erecta irrespective of the levels of $\mathrm{Pb}$ contamination Glomus mosseae inoculation significantly $(\mathrm{p} \leq 0.05)$ increased $\mathrm{Cu}$ uptake of Tagetes erecta at $500 \mathrm{mg} \mathrm{kg}^{-1}$ of $\mathrm{Cu}$ concentration of a polluted soil. In contaminated soil, containing $50 \mathrm{mg} \mathrm{kg}{ }^{-1} \mathrm{~Pb}$ Glomus mosseae significantly $(\mathrm{p} \leq 0.05)$ increased $\mathrm{Pb}$ uptake in Tagetes erecta.
\end{abstract}

Keywords: Arbuscular Mycorrhiza, Heavy Metals, Tagetes Erecta, Glomus Mosseae, Hyperaccumulation

\section{Introduction}

In many parts of the world, the problem of environmental pollution has assumed an unprecedented proportion (Giuffré et al., 2012). Industrial revolution and increase in world population have inevitably been responsible for environmental pollution. Many events of coming decades already were predetermined with past and present activities of man on planet earth. Major pollution sources include point sources such as emissions, waste discharge from industries, vehicle exhaustion and nonpoint sources such as soluble salts (natural and artificial), insecticides/pesticides, disposal of industrial and municipal waste and excessive use of fertilizers (Olarenwaju et al., 2009). About $60 \%$ of these pollutants are referred to as heavy metals (Kamnev, 2003). Heavy metals are the most insidious pollutants because of their non-biodegradable nature and properties that affect all forms of ecological system (Saba et al., 2013). Despite the toxicity potentials of heavy metals, some are 
essential for normal healthy growth and reproduction at low but critical concentration. Unfortunately, developing countries of the world such as Nigeria could not afford the cost of remediation because of lack of adequate fund, misplacement of priorities, poor management strategy and low level of technology advancement to handle problems of pollution. To address these challenges, the application of a method that offers a cost effective and an environmentally friendly approach that utilizes bio-agents with appropriate techniques such as phytoextraction should be employed. Although, over 500 plants species had been identified as metalliferous or hyperaccumulators of metals from polluted sites, majority of which are exotic species with adaption to a species natural habitat (Krämer, 2010). Thus, the need to also access the phytoremedial potentials of some indigenous plant species or weeds whose potential are yet to be known, as hidden potentials of some commonly grown weeds needs to be unveiled for human benefit particularly as it relates to improving the quality of the environment.

Hence, this study investigate the ability of the weed plants as African Marigold (Tagetes erecta) to extract heavy metals from polluted soils.

\section{Material and Methods}

\section{Experimental Site}

The greenhouse experiment was carried out at the Faculty of Agriculture, Obafemi Awolowo University (OAU).

\section{Experimental Procedure}

A total of 120 plastic pots with drainage holes at the bottom with $3 \mathrm{~kg}$ each of air-dried soil. The soil that was collected was air dried and sterilized at $121^{\circ} \mathrm{C}$ for $2 \mathrm{~h}$ using autoclave to eliminate native mycorrhiza fungi propagules as well as other microorganisms present in the soil and sieved using $2 \mathrm{~mm}$ mesh. These concentrations were used to contaminate the soil in the pots. The soil was left for four days for equilibration before mycorrhiza treatments were applied. The mycorrhiza treatment consisted of 30 pots each of Glomus mosseae (mycorrhiza) and non-mycorrhiza respectively. Soil mycorrhiza inoculum of Glomus mosseae was applied at the rate of $12 \mathrm{~g}$ per pot of 100 spores. Five seeds of Tagetes erecta were planted per pot and were thinned to two stands per pot at two weeks after planting and replicated 3 times in a completely randomized design. The pots were maintained weed free and pots were watered regularly with deionized water to moisture capacity to maintain soil moisture at $70 \%$ of field water holding capacity.

\section{Parameters Determined}

At the end of twelve weeks after planting, plant growth, percentage of root colonization by Arbuscular Mycorrhizal fungi, soil analysis, $\mathrm{N}, \mathrm{K}, \mathrm{Ca}, \mathrm{Mg}, \mathrm{Zn}, \mathrm{Pb}, \mathrm{Fe}, \mathrm{Cd}, \mathrm{Cu}, \mathrm{K}$ and $\mathrm{Na}$ were all determined based on series of methods used at the end of twelve weeks after planting.

\section{Statistical Analyses}

A statistical comparison of means was made with analysis of variance (ANOVA) and treatment means were separated using Duncan Multiple Range Test at $\mathrm{p}<0.05$ available in the SPSS. 16 statistical packages version.

\section{Results and Discussion}

The results of the pre-experiment analysis conducted on the soil samples used for this study indicated that the soil was sandy loam $(84.4 \%$ and $15.4 \%$, sand and silt composition respectively) and were characterized by mean $\mathrm{pH}$ of 6.5 , available $\mathrm{P} 12.8 \mathrm{mg} \mathrm{kg}^{-1}, 2.1 \mathrm{mg} \mathrm{kg}^{-1}$ Organic carbon, Nitrogen $0.22 \mathrm{mg} \mathrm{kg}^{-1}$ and $\mathrm{Ca}^{2+}$ was $2.02 \mathrm{mg} \mathrm{kg}^{-1}$. The $\mathrm{Pb}$ and $\mathrm{Cu}$ contents of the soil were $0.22 \mathrm{mg} \mathrm{kg}^{-1}$ and $0.74 \mathrm{mg} \mathrm{kg}^{-1}$. The physical and chemical characteristics of soil used in the experiment is presented in the Table 1 above and Fig. 1 shows the weed plants of African Marigold (Tagetes erecta) planted on the soil.

\section{Growth of T. erecta Different Concentrations of $\mathrm{Cu}$ in Soil with Glomus Mosseae Inoculation.}

\section{Number of Leaves}

The response of leaves of $T$. erecta to different levels of $\mathrm{Cu}$ concentration varied with Glomus mosseae inoculation. In an uncontaminated $\mathrm{Cu}\left(0 \mathrm{mg} \mathrm{kg}^{-1}\right)$, the effect of Glomus mosseae inoculation on the number of leaves in $T$. erecta was evident at 6, 10 and 12 Weeks After Planting (WAP). However, at $125 \mathrm{mg} \mathrm{kg}^{-1}$ of $\mathrm{Cu}$ contamination, the effect of Glomus mosseae became evident at 12 weeks after planting on leaf development $T$. erecta.

Table 1: Physical and chemical characteristics of soil used in the experiment

\begin{tabular}{ll}
\hline Characteristics & Value \\
\hline $\mathrm{Sand}\left(\mathrm{gkg}^{-1}\right)$ & 760 \\
$\mathrm{Silt}\left(\mathrm{gkg}^{-1}\right)$ & 140 \\
$\mathrm{Clay}\left(\mathrm{gkg}^{-1}\right)$ & 100 \\
$\mathrm{pH}$ in water $(\mathrm{H} 2 \mathrm{O})$ & 6.50 \\
Organic Carbon $\left(\mathrm{gkg}^{-1}\right)$ & 2.06 \\
Available phosphorus $\left(\mathrm{gkg}^{-1}\right)$ & 12.81 \\
Nitrogen $\left(\mathrm{gkg}^{-1}\right)$ & 0.22 \\
Exchangeable cations $\left(\mathrm{cmol} \mathrm{kg}^{-1}\right)$ & \\
$\mathrm{Na}^{+}$ & 0.56 \\
$\mathrm{~K}^{+}$ & 0.51 \\
$\mathrm{Ca}^{2+}$ & 2.02 \\
$\mathrm{Mg}^{2+}$ & 0.54 \\
$\mathrm{Textural} \mathrm{class}$ & Sandy loam \\
$\mathrm{Cu}\left(\mathrm{mgkg}^{-1}\right)$ & 0.74 \\
$\mathrm{~Pb}\left(\mathrm{mgkg}^{-1}\right)$ & 0.22 \\
\hline
\end{tabular}




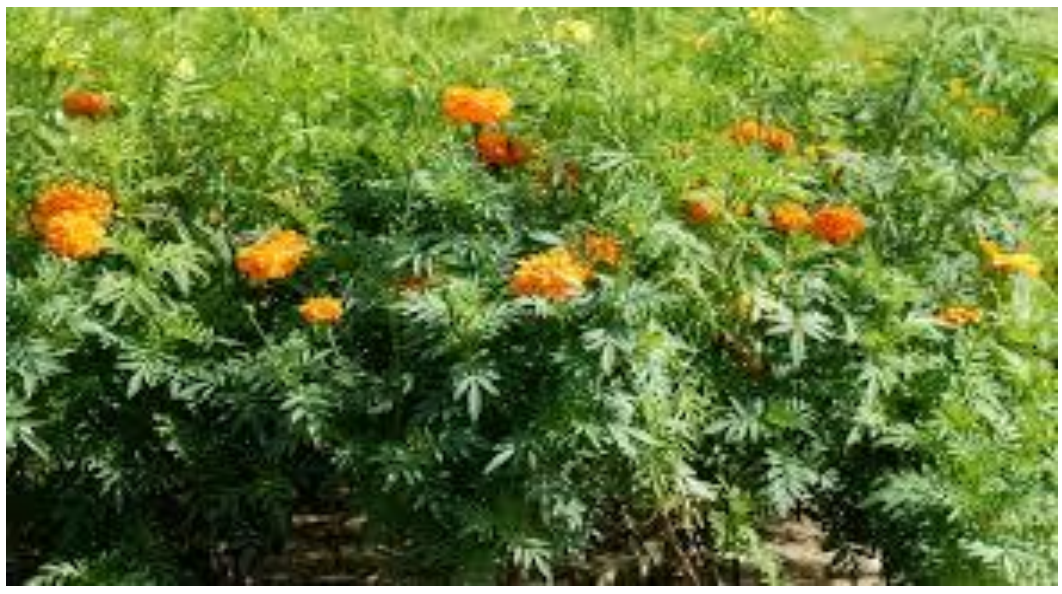

Fig. 1: Tagetes erecta

With the increase in the level of $\mathrm{Cu}$ contamination to $250 \mathrm{mg} \mathrm{kg}^{-1}$, the number of leaves in $T$. erecta was enhanced by Glomus mosseae inoculation at 4-12 WAP, (Fig. 2).

The response of leaf of $T$. erecta to different levels of $\mathrm{Pb}$ contamination under the influence of Glomus mosseae varied with the concentrations of $\mathrm{Pb}$. In the $0 \mathrm{mg} \mathrm{Pb} \mathrm{kg}-1$ contaminated soil, Glomus mosseae inoculation significantly $(p \leq 0.05)$ enhanced the number of leaf (Fig. 5). When the soil was contaminated with $25 \mathrm{mg} \mathrm{kg}^{-1}$ of $\mathrm{Pb}$, Glomus mosseae improved leaf production $T$. erecta. At $100 \mathrm{mg} \mathrm{Pb} \mathrm{kg}^{-1}$, there was no effect of Glomus mosseae on the effect of Glomus mosseae on number of leaves.

\section{Plant Height}

In an uncontaminated $\mathrm{Cu}$ soil $\left(0 \mathrm{mg} \mathrm{kg} \mathrm{kg}^{-1}\right)$, Glomus mosseae enhanced the plant height of T. erecta at 6 to 12 WAP. At $125 \mathrm{mg} \mathrm{kg}^{-1}$ of $\mathrm{Cu}$ contamination, plant height of $T$. erecta was enhanced by Glomus mosseae inoculation except at 12 weeks after planting in $T$. erecta, there was no marked effect of mycorrhiza inoculation on the plant height. Similar, trend was also observed for $T$. erecta $250 \mathrm{mg} \mathrm{kg}^{-1} \mathrm{Cu}$ contamination.

When the $\mathrm{Cu}$ contamination was doubled $(500 \mathrm{mg}$ $\mathrm{kg}^{-1}$ ) the effect of Glomus mosseae significantly $(\mathrm{p} \leq 0.05)$ enhanced the plant height in both plants, particularly at 10 to 12 WAP (Fig. 3d). At a higher concentration (1000 $\mathrm{mg} \mathrm{kg}^{-1}$ ) the effects of mycorrhizal inoculation on the plant height of $T$. erecta significantly $(\mathrm{p} \leq 0.05)$ increase the plant height at early stage of development (2 to 4 weeks after planting) (Fig. 3).

\section{Stem Girth}

At $0 \mathrm{mg} \mathrm{kg}-1$ of $\mathrm{Cu}$ soil contamination, mycorrhizal inoculation did not have appreciable effect on the stem girth of $T$. erecta except at 4 and $10 \mathrm{WAP}$, where Glomus mosseae was more pronounced (Fig. 4a). Similar trend was also observed at the level of $125 \mathrm{mg}$ $\mathrm{kg}^{-1}$ of $\mathrm{Cu}$ contamination (Fig. 4b). Mycorrhizal inoculation increased the stem girth of $T$. erecta at 8 to
12 Weeks After Planting (WAP) under $500 \mathrm{mg} \mathrm{kg}^{-1}$ of $\mathrm{Cu}$ contaminated soil. At $1000 \mathrm{mg} \mathrm{kg}^{-1}$ concentration of $\mathrm{Cu}$, Glomus mosseae inoculation significantly $(\mathrm{p} \leq 0.05)$ enhanced the stem girth of both $T$. erecta, at 8 to 12 Weeks After Planting (WAP) in T. erecta.

\section{Growth of T. erecta Different Concentrations of $\mathrm{Pb}$ in Soil with Glomus mosseae Inoculation}

\section{Number of Leaves}

The response of leaf of $T$. erecta to different levels of $\mathrm{Pb}$ contamination under the influence of Glomus mosseae varied with the concentrations of $\mathrm{Pb}$. In the $0 \mathrm{mg} \mathrm{Pb} \mathrm{kg}-1$ contaminated soil, Glomus mosseae inoculation significantly $(\mathrm{p} \leq 0.05)$ enhanced the number of leaf. When the soil was contaminated with $25 \mathrm{mg} \mathrm{kg}^{-1}$ of $\mathrm{Pb}$, Glomus mosseae improved leaf production in both T. erecta. At 100 $\mathrm{mg} \mathrm{Pb} \mathrm{kg}{ }^{-1}$, there was no effect of Glomus mosseae on the effect of Glomus mosseae on number of leaves.

In an uncontaminated $\left(0 \mathrm{mg} \mathrm{kg} \mathrm{kg}^{-1}\right)$ soil under $\mathrm{Pb}$ treatment experiment, the height of Glomus mosseae inoculated $T$. erecta was higher than those with noninoculated plants.

\section{Plant Height}

However, at $50 \mathrm{mg} \mathrm{Pb} \mathrm{kg}^{-1}$ soil contamination, the influence of Glomus mosseae on plant height of T. erecta was reduced throughout the period of plant growth. The response of plant height of $T$. erecta to $75 \mathrm{mg} \mathrm{Pb} \mathrm{kg}^{-1}$ contaminated soil was significantly $(\mathrm{p} \leq 0.05)$ enhanced by Glomus mosseae inoculation at 12 WAP. At a higher concentration of $100 \mathrm{mg} \mathrm{kg}^{-1}$ of $\mathrm{Pb}$, the plant plants height did not follow a definite pattern with respect to mycorrhizal inoculation (Fig. 6).

\section{Stem Girth}

At $25 \mathrm{mg} \mathrm{Pb} \mathrm{kg}$, Glomus mosseae inoculation significantly $(\mathrm{p} \leq 0.05)$ enhanced the stem girth of $T$. erecta 4 WAP, 10 WAP. The influence of Glomus 
mosseae on stem girth of $T$. erecta was observed at 50 $\mathrm{mg} \mathrm{Pb} \mathrm{\textrm {kg } ^ { - 1 }}$ soil contamination. Glomus mosseae significantly $(\mathrm{p} \leq 0.05)$ enhanced the stem girth of $T$. erecta at $75 \mathrm{mg} \mathrm{Pb} \mathrm{kg}^{-1}$ contamination (Fig. 7).
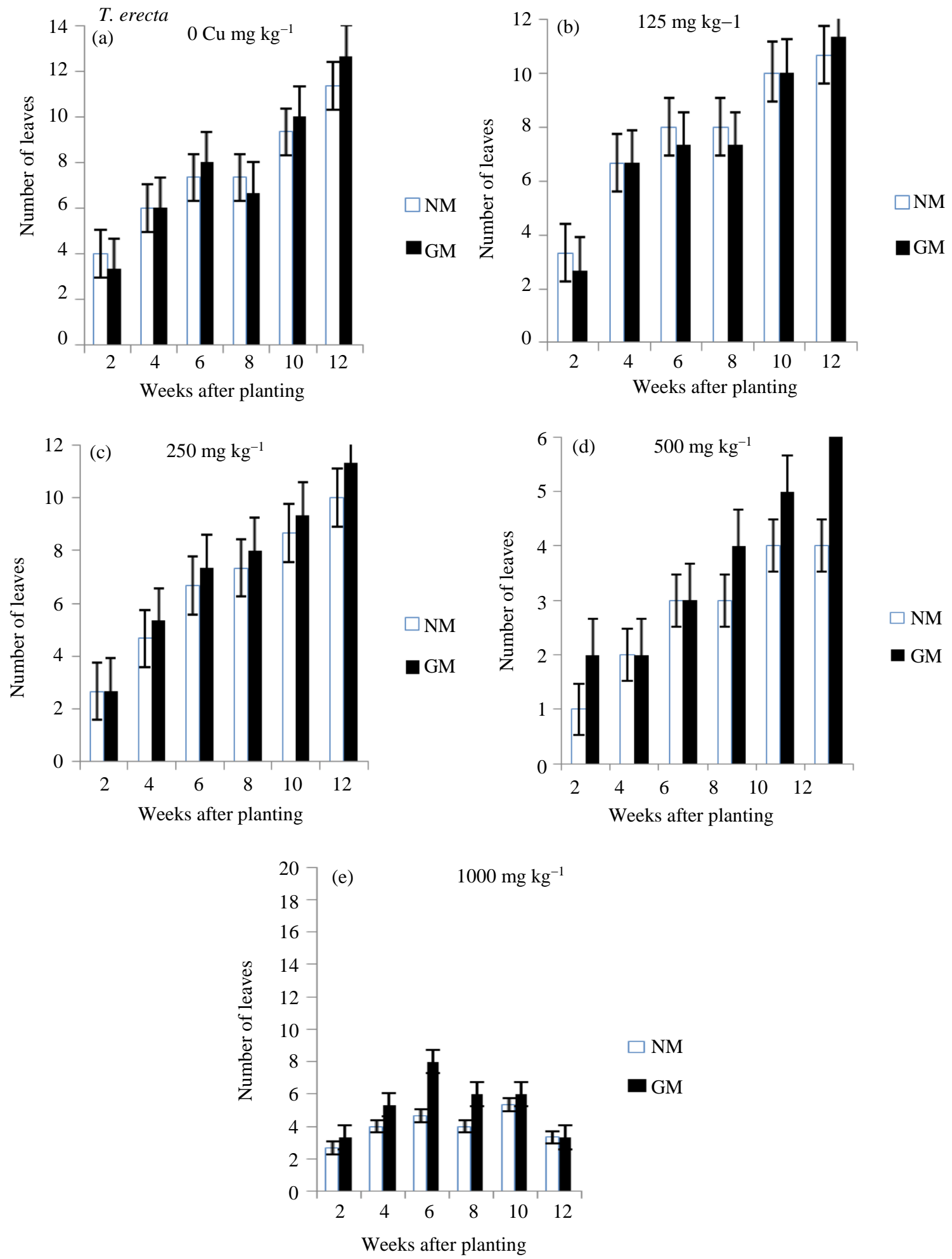

Fig. 2: Plant leave of T. erecta inoculated with Glomus Mosseae (GM) in 0, 125, 250, 500, $1000 \mathrm{mg} \mathrm{kg}^{-1}$ Copper contamination soil. Legend: NM-------Non Mycorrhiza; GM-------Glomus Mossae (with Mycorrhiza) 

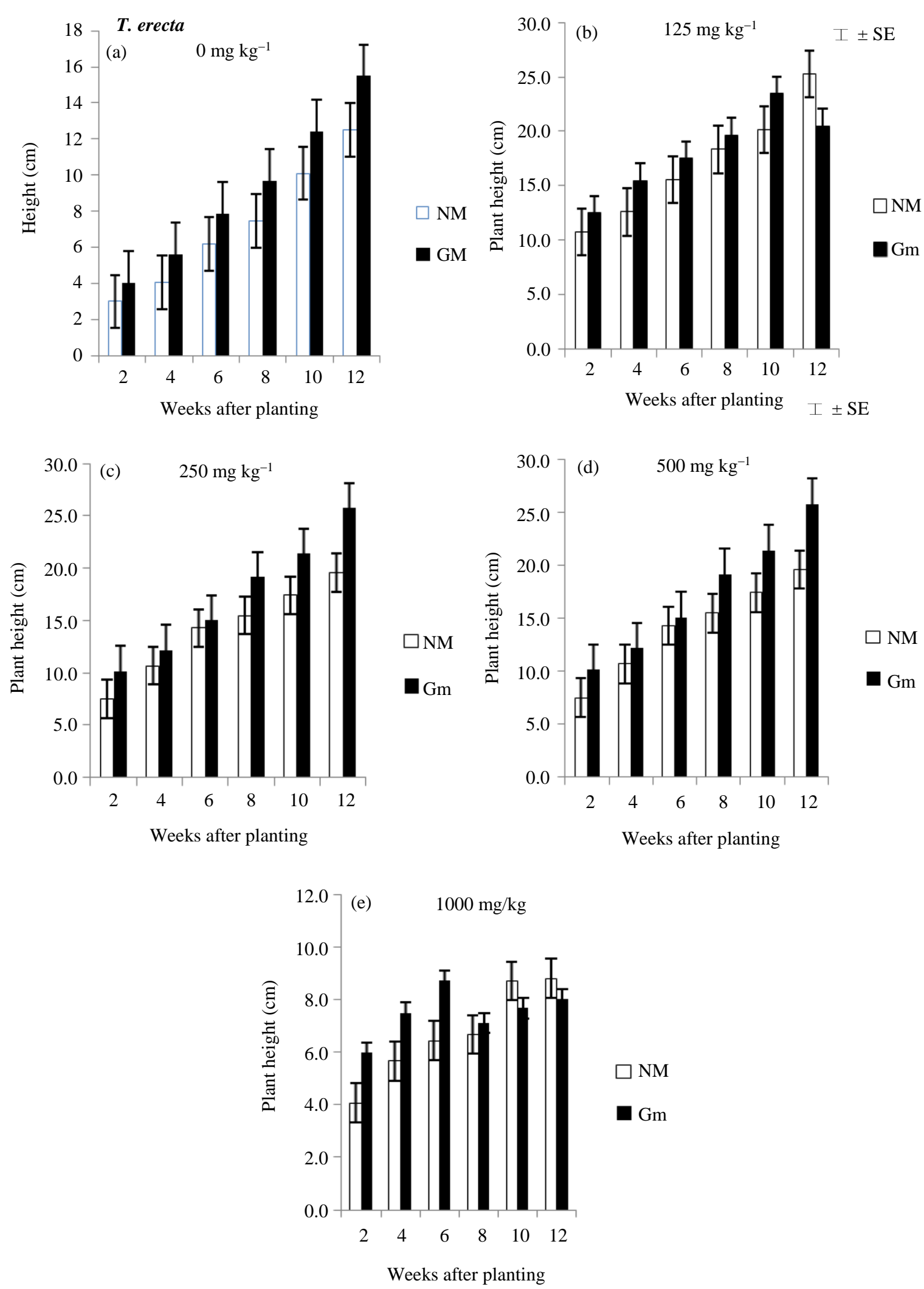

Fig. 3: Plant Height of T. erecta inoculated with Glomus mosseae (GM) in 0, 125, 250, 500, $1000 \mathrm{mg} \mathrm{kg}^{-1}$ Copper contamination soil. Legend: NM- Non-mycorrhizal; GM- Glomus mosseae (with Mycorrihiza) 

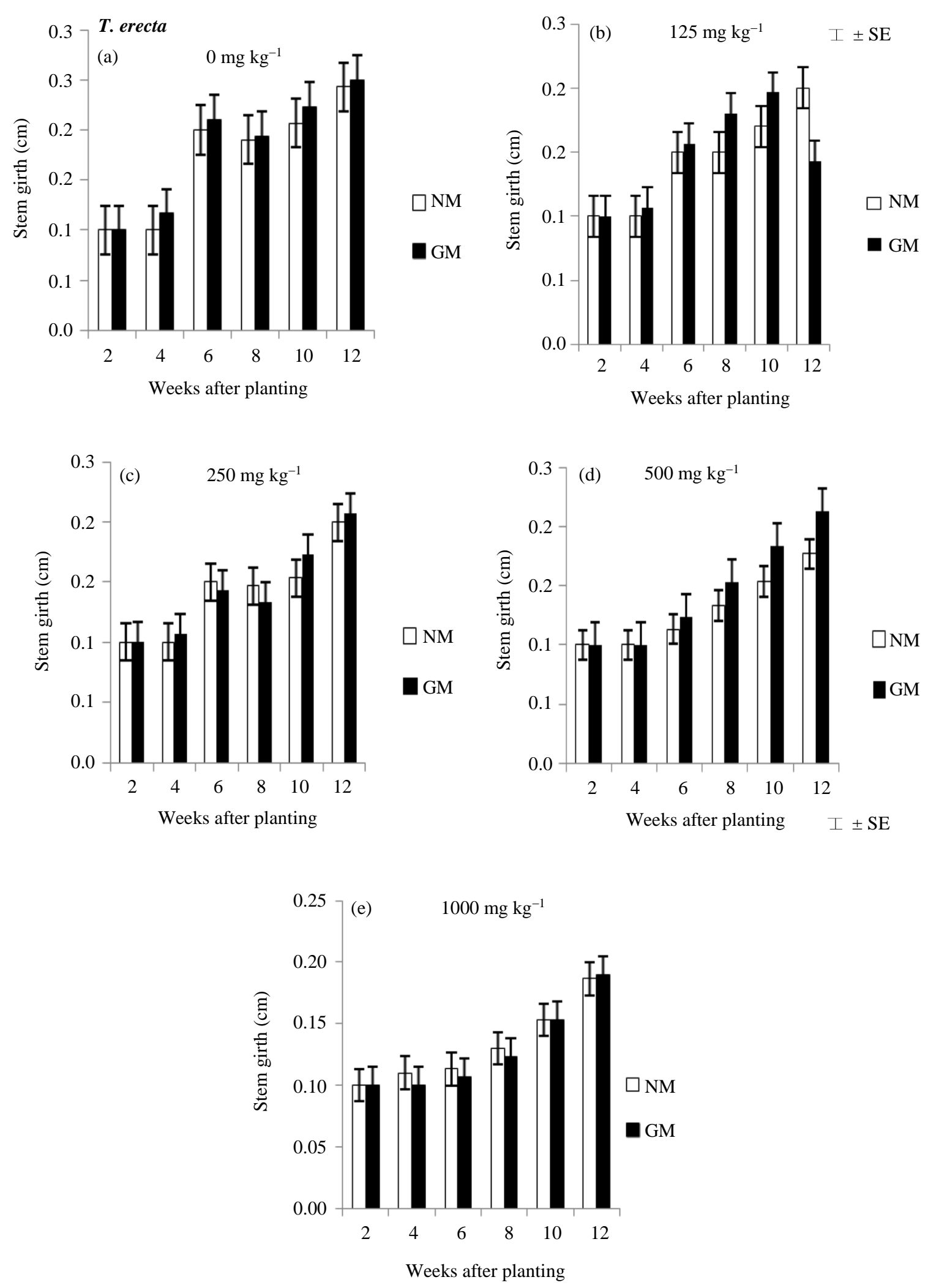

Fig. 4: Stem Girth of T. erecta inoculated with Glomus mosseae (GM) in 0, 125, 250, 500, $1000 \mathrm{mg} \mathrm{kg}^{-1}$ Copper contamination soil. Legend: NM- Non-mycorrhizal; GM- Glomus mosseae (with Mycorrihiza) 

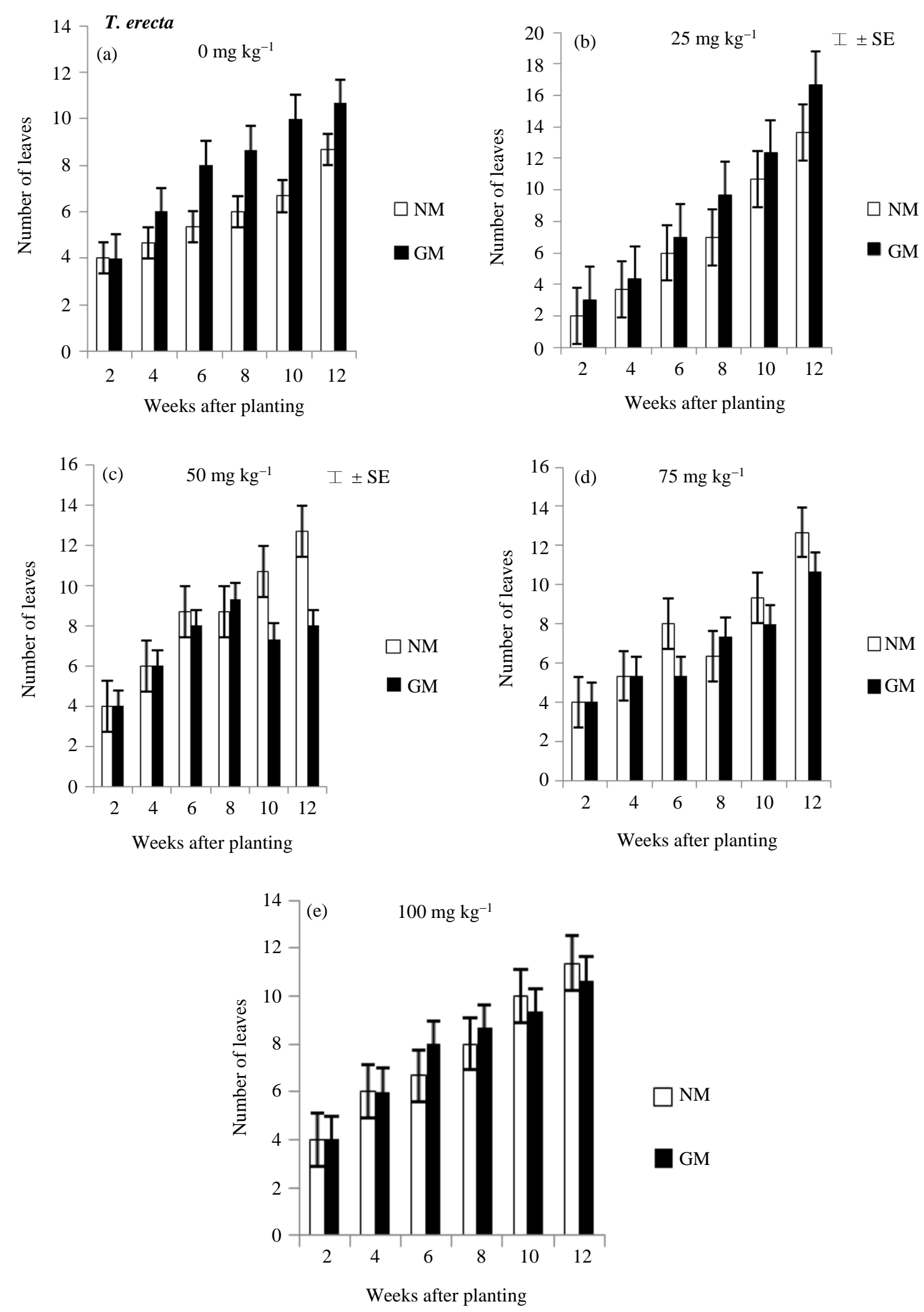

Fig. 5: Number of Leaves of T. erecta inoculated with Glomus mosseae (GM) in 0, 25, 50, 75, $100 \mathrm{mg} \mathrm{kg}^{-1}$ Lead contamination soil. Legend: NM- Non-mycorrhizal; GM- Glomus mosseae. (with Mycorrihiza) 

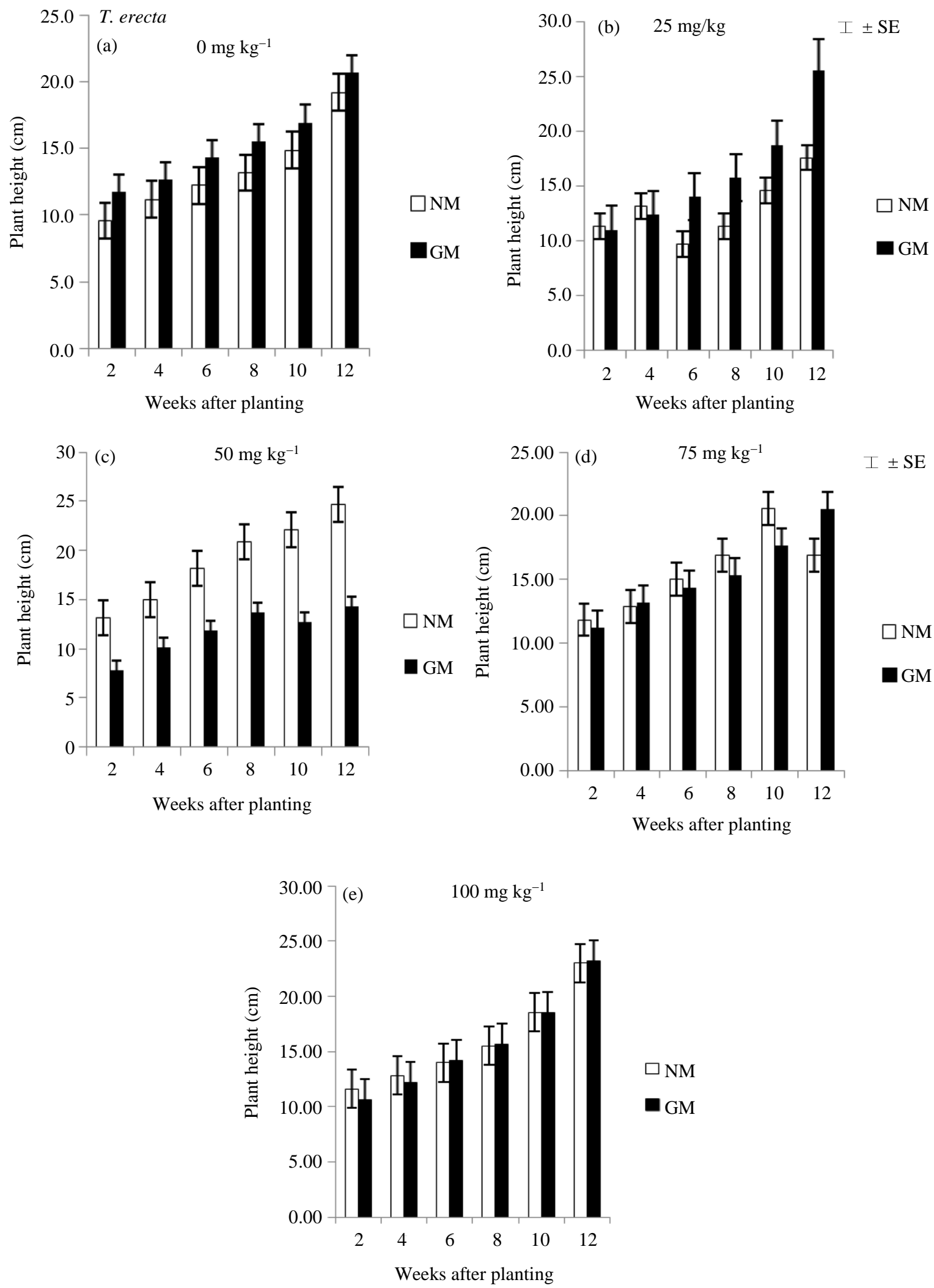

Fig. 6: Plant Height of $T$. erecta inoculated with Glomus mosseae (GM) in 0, 25, 50, 75, $100 \mathrm{mg} \mathrm{kg}^{-1}$ lead contamination soil. Legend: NM- Non-mycorrhizal; GM- Glomus mosseae. (with Mycorrihiza) 

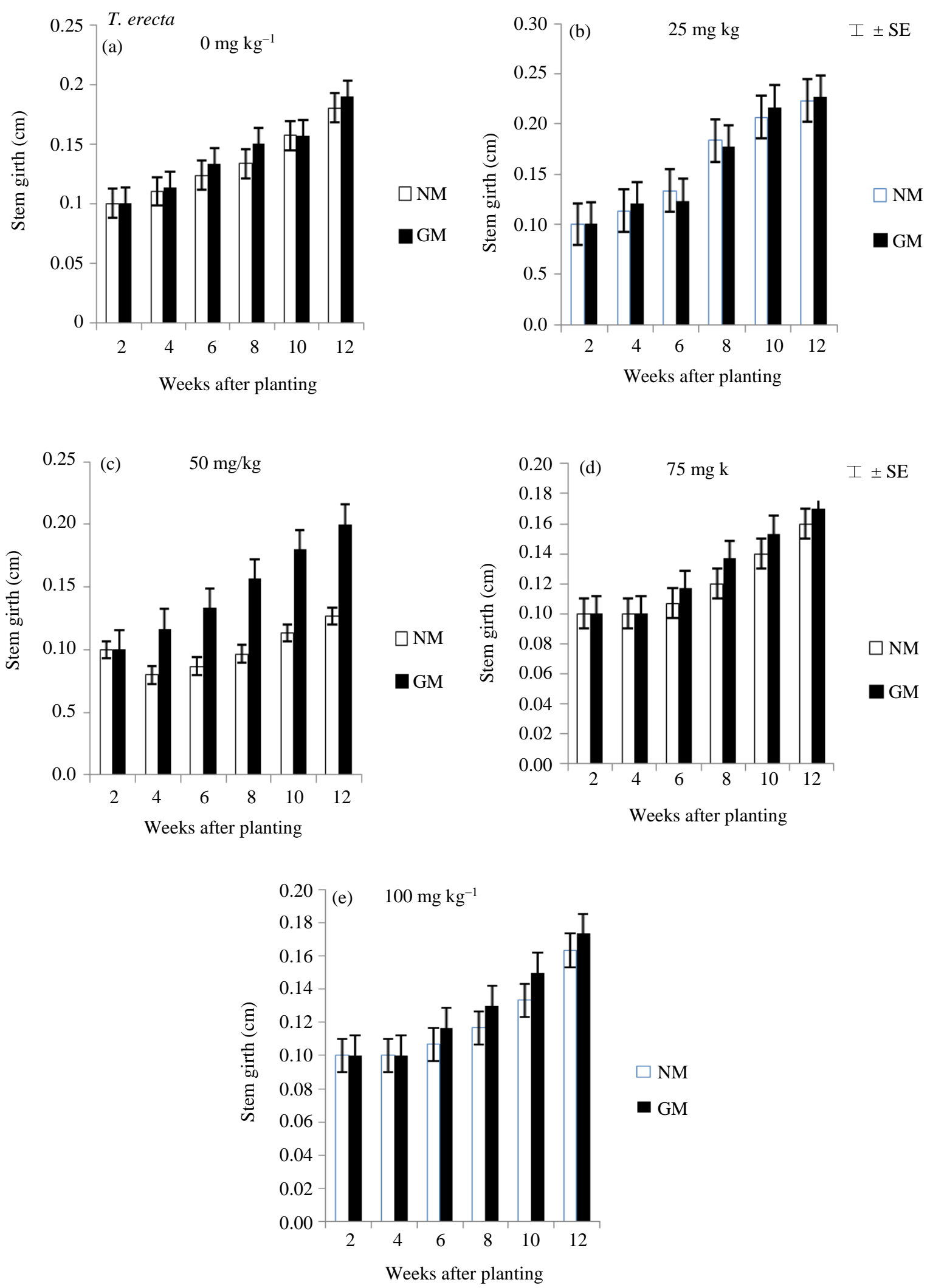

Fig. 7: Stem Girth of T. erecta inoculated with Glomus mosseae (GM) in 0, 25, 50, 75, $100 \mathrm{mg} \mathrm{kg}^{-1}$ Lead contamination soil. Legend: NM- Non-mycorrhizal; GM- Glomus mosseae. (with Mycorrihiza) 
Influence of Arbuscular Mycorrizal (AM) Fungi on the Nutrient Uptake of $\mathrm{T}$. erecta in $\mathrm{Cu}$ and $\mathrm{Pb}$ in Contaminated Soil

Glomus mosseae inoculation enhanced the $\mathrm{N}$ uptake of T. erecta in $\mathrm{Cu}$ polluted soil, the highest $\mathrm{N}$ uptake of $T$. erecta in $\mathrm{Cu}$ polluted soils occurred at $250 \mathrm{mg} \mathrm{Cu} \mathrm{kg}{ }^{-1}$ contamination. The $\mathrm{P}$ uptake decreased as the concentration of contaminant increased in Glomus mosseae inoculated plants. There was a marked effect of Glomus mosseae inoculation on the $\mathrm{P}$ uptake of $T$. erecta compared with noninoculated plants. The $\mathrm{Zn}$ uptake decreased as the $\mathrm{Cu}$ concentration increased in Glomus mosseae inoculated plant. Glomus mosseae had significantly $(\mathrm{p} \leq 0.05)$ enhanced the uptake of $\mathrm{Fe}$ in $T$. erecta. Fe uptake by $T$. erecta decreased as the $\mathrm{Cu}$ concentration increases in the soil (Table 2).

In the uncontaminated soil, Glomus mosseae inoculation improved the $\mathrm{N}, \mathrm{P}, \mathrm{K}$ uptakes However, in the 25 and $50 \mathrm{~Pb} \mathrm{~kg}^{-1}$ contaminated soil, mycorrhizzal inoculation enhanced $\mathrm{N}, \mathrm{P}$ and $\mathrm{K}$ contents of $T$. erecta. Mycorrhizal inoculation enhanced $\mathrm{Zn}$ uptake at $250 \mathrm{mg} \mathrm{Pb} \mathrm{kg}{ }^{-1}$ contamination. Fe uptake was significant at $50 \mathrm{mg} \mathrm{Pb} \mathrm{kg}{ }^{-1}$ under Glomus mosseae inoculation (Table 3).

Influence of Arbuscular Mycorrizal (AM) Fungi on the Plant Dry Weight, $\mathrm{Cu}$ and Pb uptakes in T. erecta

Glomus mosseae inoculation enhanced plant dry weight in $\mathrm{Cu}$ contaminated soil irrespective of the level of the concentrations except at $1000 \mathrm{mg} \mathrm{kg}^{-1} \mathrm{Cu}$. The uptake of $\mathrm{Cu}$ by $T$. erecta as influenced by Glomus mosseae is shown in $\mathrm{Cu}$ uptake increased with increasing level of soil contamination to a threshold level and then declined. Threshold level of $\mathrm{Cu}$ uptake with non-inoculated plants was at $250 \mathrm{mg} \mathrm{kg}^{-1}$ contamination, while with Glomus mosseae was at $500 \mathrm{mg} \mathrm{kg}^{-1}$ (Table 4).

Similar to $\mathrm{Cu}$ contaminated soil, the Glomus mosseae inoculation influenced the plant dry weight of $T$. erecta in $\mathrm{Pb}$ contaminated soils (Table 5). Glomus mosseae increased $\mathrm{Pb}$ uptake in $T$. erecta with increased level of contamination to a threshold before it declined. Plant optimum uptake for lead was at 75 $\mathrm{mg} \mathrm{kg}{ }^{-1}$ contamination level with Glomus mosseae.

Table 2: Effect of Glomus mosseae on Plant nutrient of T. erecta under different concentrations of Cu Contamination

\begin{tabular}{|c|c|c|c|c|c|c|c|c|c|c|}
\hline Trt & $\mathrm{Cu}$ Contamination & $\mathrm{N}$ & $\mathrm{P}$ & $\mathrm{K}$ & $\mathrm{Ca} \mathrm{mgkg}^{-1}$ & $\mathrm{Mg}$ & $\mathrm{Na}$ & $\mathrm{Fe}$ & $\mathrm{Mn}$ & $\mathrm{Zn}$ \\
\hline & Conc $\mathrm{mgkg}^{-1}$ & & & & & & & & & \\
\hline \multirow[t]{5}{*}{ NM } & 0 & $1.16 \mathrm{c}$ & $0.23 b$ & $0.22 \mathrm{c}$ & $1.17 \mathrm{c}$ & $0.40 \mathrm{~b}$ & $0.16 \mathrm{c}$ & $5.39 \mathrm{~d}$ & $77.9 \mathrm{c}$ & $2.82 \mathrm{~b}$ \\
\hline & 125 & $0.77 b$ & $0.15 c$ & $0.16 \mathrm{e}$ & $0.83 \mathrm{e}$ & $0.35 c$ & $0.11 \mathrm{~d}$ & $5.47 \mathrm{c}$ & $68.5 \mathrm{~d}$ & $3.03 \mathrm{a}$ \\
\hline & 250 & $1.04 \mathrm{c}$ & $0.22 b$ & $0.17 \mathrm{e}$ & $1.15 \mathrm{c}$ & $0.42 b$ & $0.12 \mathrm{~d}$ & $7.42 b$ & $72.65 \mathrm{c}$ & $3.10 \mathrm{a}$ \\
\hline & 500 & $0.45 \mathrm{~d}$ & $0.13 \mathrm{~d}$ & $0.15 \mathrm{e}$ & $1.03 \mathrm{~d}$ & $0.37 \mathrm{~d}$ & $0.21 \mathrm{c}$ & $3.47 \mathrm{e}$ & $42.6 \mathrm{~d}$ & $1.48 \mathrm{~d}$ \\
\hline & 1000 & $0.72 \mathrm{c}$ & $0.10 \mathrm{e}$ & $0.23 \mathrm{c}$ & $1.30 \mathrm{~b}$ & $0.24 \mathrm{~d}$ & $0.81 \mathrm{a}$ & $8.16 \mathrm{~b}$ & $10.2 b$ & $1.79 \mathrm{c}$ \\
\hline \multirow[t]{5}{*}{ GM } & 0 & $1.26 \mathrm{~b}$ & $0.27 b$ & $0.22 \mathrm{c}$ & $0.57 \mathrm{e}$ & $0.51 b$ & $0.20 \mathrm{c}$ & $5.47 \mathrm{c}$ & $98.35 \mathrm{c}$ & $3.02 \mathrm{a}$ \\
\hline & 125 & $2.29 \mathrm{~b}$ & $0.44 \mathrm{a}$ & $0.31 b$ & $1.48 b$ & $0.51 b$ & $0.33 b$ & $10.27 \mathrm{~b}$ & $113.50 \mathrm{a}$ & $3.52 \mathrm{a}$ \\
\hline & 250 & $2.82 \mathrm{a}$ & $0.52 \mathrm{a}$ & $0.37 \mathrm{a}$ & $1.61 \mathrm{a}$ & $0.64 \mathrm{a}$ & $0.44 b$ & $10.88 \mathrm{a}$ & $107.65 b$ & $3.23 \mathrm{a}$ \\
\hline & 500 & $0.69 \mathrm{c}$ & $0.26 b$ & $0.18 \mathrm{e}$ & $1.02 \mathrm{~d}$ & $0.37 \mathrm{~d}$ & $0.20 \mathrm{c}$ & $3.88 \mathrm{e}$ & $40.48 \mathrm{~d}$ & $2.33 b$ \\
\hline & 1000 & $0.45 \mathrm{~d}$ & $0.13 \mathrm{~d}$ & $0.16 \mathrm{e}$ & $0.37 \mathrm{e}$ & $0.39 \mathrm{c}$ & $0.20 \mathrm{c}$ & $9.16 b$ & $31.92 \mathrm{e}$ & $2.04 \mathrm{c}$ \\
\hline
\end{tabular}

Values in the same group followed by the same letter did not differ significantly at $\mathrm{p} \leq 0.05$ using Duncan Multiple Range Test.

Legend: Trt- Treatment, NM-Non-mycorrhiza; GM- Glomus mossea

Table 3: Effect of Glomus mosseae on Plant nutrient of T.erecta under different concentrations of $\mathrm{Pb}$ contamin

\begin{tabular}{lllllllllll}
\hline Trt & Pb Contamination & $\mathrm{N}$ & $\mathrm{P}$ & $\mathrm{K}$ & $\mathrm{Ca} \mathrm{mgkg}{ }^{-1}$ & $\mathrm{Mg}$ & $\mathrm{Na}$ & $\mathrm{Fe}$ & $\mathrm{Mn}$ & $\mathrm{Zn}$ \\
\hline \multirow{3}{*}{$\mathrm{NM}$} & ${\text { Conc } \mathrm{mkg}^{-1}}$ & & & & & & & & & \\
& 25 & $0.25 \mathrm{~d}$ & $0.16 \mathrm{~d}$ & $0.16 \mathrm{c}$ & $0.39 \mathrm{e}$ & $0.29 \mathrm{~d}$ & $0.14 \mathrm{~d}$ & $7.02 \mathrm{~d}$ & $2.03 \mathrm{~b}$ & $86.50 \mathrm{~b}$ \\
& 50 & $0.49 \mathrm{c}$ & $0.18 \mathrm{~d}$ & $0.23 \mathrm{~b}$ & $0.45 \mathrm{c}$ & $0.34 \mathrm{c}$ & $0.19 \mathrm{c}$ & $7.98 \mathrm{c}$ & $2.02 \mathrm{~b}$ & $82.55 \mathrm{~b}$ \\
& 75 & $0.50 \mathrm{c}$ & $0.28 \mathrm{c}$ & $0.14 \mathrm{~d}$ & $0.47 \mathrm{c}$ & $0.33 \mathrm{c}$ & $0.27 \mathrm{~b}$ & $6.27 \mathrm{~d}$ & $1.93 \mathrm{c}$ & $86.89 \mathrm{~b}$ \\
& 100 & $1.07 \mathrm{~d}$ & $0.24 \mathrm{c}$ & $0.13 \mathrm{~d}$ & $0.10 \mathrm{e}$ & $0.54 \mathrm{a}$ & $0.21 \mathrm{c}$ & $2.98 \mathrm{e}$ & $1.73 \mathrm{c}$ & $27.00 \mathrm{c}$ \\
$\mathrm{GM}$ & 0 & $1.85 \mathrm{~b}$ & $0.13 \mathrm{e}$ & $0.17 \mathrm{c}$ & $0.40 \mathrm{c}$ & $0.28 \mathrm{~d}$ & $0.20 \mathrm{c}$ & $4.94 \mathrm{e}$ & $1.63 \mathrm{~d}$ & $25.50 \mathrm{c}$ \\
& 25 & $1.18 \mathrm{c}$ & $0.35 \mathrm{~b}$ & $0.22 \mathrm{~b}$ & $0.39 \mathrm{e}$ & $0.34 \mathrm{c}$ & $0.20 \mathrm{c}$ & $7.02 \mathrm{~d}$ & $2.08 \mathrm{~b}$ & $101.75 \mathrm{a}$ \\
& 50 & $2.49 \mathrm{a}$ & $0.38 \mathrm{~b}$ & $0.24 \mathrm{~b}$ & $0.73 \mathrm{~d}$ & $0.33 \mathrm{c}$ & $0.29 \mathrm{~b}$ & $8.08 \mathrm{~b}$ & $2.13 \mathrm{a}$ & $107.20 \mathrm{a}$ \\
& 75 & $1.95 \mathrm{~b}$ & $0.47 \mathrm{a}$ & $0.98 \mathrm{a}$ & $1.24 \mathrm{a}$ & $0.40 \mathrm{~b}$ & $0.31 \mathrm{a}$ & $8.53 \mathrm{a}$ & $2.13 \mathrm{a}$ & $85.56 \mathrm{~b}$ \\
& 100 & $1.07 \mathrm{~d}$ & $0.28 \mathrm{c}$ & $0.19 \mathrm{~b}$ & $1.07 \mathrm{~b}$ & $0.41 \mathrm{~b}$ & $0.20 \mathrm{c}$ & $6.27 \mathrm{~d}$ & $1.87 \mathrm{c}$ & $83.55 \mathrm{~b}$ \\
& $1.11 \mathrm{~d}$ & $0.17 \mathrm{~d}$ & $0.16 \mathrm{c}$ & $0.45 \mathrm{c}$ & $0.25 \mathrm{~d}$ & $0.16 \mathrm{~d}$ & $3.17 \mathrm{e}$ & $1.73 \mathrm{c}$ & $86.75 \mathrm{~b}$ \\
\hline
\end{tabular}

Values in the same group followed by the same letter did not differ significantly at $\mathrm{p} \leq 0.05$ using Duncan Multiple Range Test.

Legend: Trt- Treatment, NM-Non-mycorrhiza; GM- Glomus mossea 
Table 4: Effect of copper concentration uptake on the dry weight of T. erecta

\begin{tabular}{lccc}
\hline & Concentration Heavy metal $(\mathrm{Cu})$ & $\begin{array}{c}\text { Dry weight of } \\
\text { uptake }(\mathrm{mg} / \mathrm{plant})\end{array}$ & plant $(\mathrm{g} / \mathrm{plant})$ \\
\hline NM & Levels $\left(\mathrm{mg} \mathrm{kg}^{-1}\right)$ & $9.32 \mathrm{e}$ & $0.10 \mathrm{e}$ \\
& 0 & $10.25 \mathrm{~d}$ & $0.12 \mathrm{e}$ \\
& 125 & $12.02 \mathrm{a}$ & $0.14 \mathrm{e}$ \\
& 250 & $11.00 \mathrm{c}$ & $0.11 \mathrm{e}$ \\
GM 0 & 500 & $11.90 \mathrm{~b}$ & $0.13 \mathrm{e}$ \\
& 1000 & $0.37 \mathrm{~d}$ & $0.40 \mathrm{c}$ \\
& 125 & $10.26 \mathrm{~d}$ & $0.47 \mathrm{~b}$ \\
& 250 & $10.86 \mathrm{~b}$ & $0.57 \mathrm{a}$ \\
\hline
\end{tabular}

Values in the same group followed by the same letter did not differ significantly at $\mathrm{p} \leq 0.05$ using Duncan Multiple Range Test.

Legend: Trt- Treatment, NM-Non-mycorrhiza; GM- Glomus mosseae

Table 5: Effect of lead concentration uptake on the dry weight of T. erecta

\begin{tabular}{lccc}
\hline Treatment & Concentration & Heavy metal $(\mathrm{Pb})$ & $\begin{array}{c}\text { Dry weight of } \\
\text { plant }(\mathrm{g} / \mathrm{plant})\end{array}$ \\
\hline $\mathrm{NM}$ & Levels $\left(\mathrm{mg} \mathrm{kg}^{-1}\right)$ & uptake $(\mathrm{mg} / \mathrm{plant})$ & $0.33 \mathrm{e}$ \\
& 0 & $1.13 \mathrm{e}$ & $0.38 \mathrm{e}$ \\
& 25 & $1.80 \mathrm{e}$ & $0.59 \mathrm{c}$ \\
& 50 & $4.05 \mathrm{c}$ & $0.47 \mathrm{~d}$ \\
$\mathrm{GM}$ & 75 & $2.34 \mathrm{c}$ & $0.33 \mathrm{e}$ \\
& 100 & $3.75 \mathrm{~b}$ & $0.40 \mathrm{~d}$ \\
& 0 & $1.70 \mathrm{e}$ & $0.60 \mathrm{c}$ \\
& 25 & $2.80 \mathrm{~d}$ & $1.23 \mathrm{~b}$ \\
& 50 & $3.81 \mathrm{~b}$ & $1.50 \mathrm{a}$ \\
\hline
\end{tabular}

Values in the same group followed by the same letter did not differ significantly at $\mathrm{p} \leq 0.05$ using Duncan Multiple Range Test.

Legend: Trt- Treatment, NM-Non-mycorrhiza; GM- Glomus mosseae

Table 6: Assessment of mycorrhizal colonization of Roots of T.erecta

\begin{tabular}{llll}
\hline Metal & $\mathrm{mg} \mathrm{kg}^{-1}$ & Mycorrhiza colonization $(\%)$ & \\
\hline & & T. erecta & $\mathrm{GM}$ \\
$\mathrm{Cu}$ & 0 & NM & $34.13 \mathrm{a}$ \\
& 125 & $3.22 \mathrm{a}$ & $23.34 \mathrm{~b}$ \\
& 250 & $2.00 \mathrm{~b}$ & $14.51 \mathrm{c}$ \\
& 500 & $1.33 \mathrm{c}$ & $11.03 \mathrm{~d}$ \\
$\mathbf{P b}$ & 1000 & $1.30 \mathrm{c}$ & $9.27 \mathrm{e}$ \\
& 0 & $1.20 \mathrm{~d}$ & $23.34 \mathrm{a}$ \\
& 25 & $1.26 \mathrm{a}$ & $19.78 \mathrm{a}$ \\
& 50 & $0.83 \mathrm{~b}$ & $11.71 \mathrm{c}$ \\
& 75 & $0.72 \mathrm{~b}$ & $6.91 \mathrm{~d}$ \\
\hline
\end{tabular}

Values in the same group followed by the same letter did not differ significantly at $\mathrm{p} \leq 0.05$ using Duncan Multiple Range Test.

Legend: NM - Non- Mycorrhizal; GM-Glomus mossea

\section{Percentage Arbuscular Mycorrhizal Root Colonization}

Perecentage mycorrhizal root colonization, for AM inoculated and non-inoculated plants are shown in Table 6 Inoculated and non-inoculated plants were both infected by $\mathrm{AM}$ fungi. Percentage root infection however was significantly higher at $\mathrm{P}<0.05$ in plants inoculated with Glomus Mosseae (GM) than in the nonmycorrhizal (GM). Greater colonization occurred between 0-250 $\mathrm{mg} \mathrm{Cu} \mathrm{kg}^{-1}$ and $0-50 \mathrm{mg} \mathrm{Pb} \mathrm{kg}^{-1}$ than at higher concentrations of contaminations.

\section{Discussion}

This study assessed the potential of indigenous plant species (Tagetes erecta) in removing $\mathrm{Cu}$ and $\mathrm{Pb}$ from contaminated soil using Glomus mosseae as an enhancer. In a view to achieve this, T. erecta was planted in greenhouse with Glomus mosseae inoculation 
under different concentration levels of $\mathrm{Cu}$ and $\mathrm{Pb}$ soil contamination. The knowledge of AM associations with $T$. erecta exposed to different levels of $\mathrm{Cu}$ and $\mathrm{Pb}$ contamination could provide a basis for alleviating the stress of heavy metal toxicity in weeds studied. Specific criteria had been put into cognizance when screening, selecting and identifying weed species with, tropical climate, primary goal of identifying potential hyperaccumulators high potential for phytoremediation of $\mathrm{Cu}$ and $\mathrm{Pb}$.

The result revealed that the growth parameters (number of leaves, plant height and stem girth) were enhanced by Glomus mossea in T. erecta. Leaf production of $T$. erecta was sustained at highest level of $(1000 \mathrm{mg}$ $\mathrm{kg}^{-1}$ ) of $\mathrm{Cu}$ concentration, similar observation had been made on the effect of AM inoculation on Solenostemon monostachyus grown in $\mathrm{Cu}$ and $\mathrm{Cd}$ contaminated soil (Awotoye et al., 2012). This suggests that AM infection offers protection against heavy metal toxicity.

The study also observed the toxicity effect of $\mathrm{Pb}$ which was noticed on the leaf production of AM inoculated $T$. erecta at $50-100 \mathrm{mg} \mathrm{kg}^{-1}$ concentrations. This indicates that the effectiveness of AM inoculation in a polluted environment may be controlled primarily by the concentration level of the contaminant. This supports the findings of Awotoye et al. (2013) on mycorrhizal inoculation of Amaranthus spinosus, Synedralla nodiflora, Sida acuta and Euphorbia heterophylla where increase $\mathrm{Pb}$ concentration had pronounced negative effects on the plant growth parameters

Arbuscular Mycorrizal fungi are able to enhance heavy metal uptake through their external mycelium, which support a wider exploration of soil volumes by spreading beyond root exploration zone (Malcova et al., 2003), thus providing access to greater volume of metals present in the rhizosphere. Another relevance of AM fungi symbiosis is that it can increase plant establishment and growth despite high levels of soil heavy metal (Enkhtuya et al., 2002), due to better nutrition (Fewtrell et al., 2003) and water availability (Augé, 2001) and soil aggregation properties (Rillig and Steingerg, 2002). It has been suggested that mycorrhizal status is related to environmental elements, especially contamination levels in soil (Smith and Read, 1997). $\mathrm{Cu}$ and $\mathrm{Pb}$ addition decreased the percent of root colonization in the present study and root colonization decreased with increasing soil $\mathrm{Cu}$ and $\mathrm{Pb}$ concentrations. This result demonstrates that high levels of soil $\mathrm{Cu}$ and $\mathrm{Pb}$ inhibited the growth of AMF and then inhibited the formation of mycorrhiza. Andrad et al. (2004) reported that the increase of $\mathrm{Pb}$ concentrations decreased the root colonization and the spore numbers, which is confirm insistent with the present study.

\section{Conclusion}

Arbuscular mycorrhiza fungi improved the growth of Tagetes erecta under high toxicity of Copper (1000 mg $\left.\mathrm{kg}^{-1}\right)$. AM fungi also improved the uptake of $\mathrm{Cu}$ and $\mathrm{Pb}$ Tagetes erecta. This study shows that AM fungi are beneficial to the phytoremediation process and that Tagetes erecta and Crotalaria juncea are suitable to grow and rehabilitate a $\mathrm{Cu}$ and $\mathrm{Pb}$ contaminated site.

\section{Acknowledgement}

Author acknowledged almighty God for His grace over this research paper and to our families a special appreciation to them.

\section{Author's Contributions}

Aina, I.O.: Participated in all experiments, coordinated the data-analysis and contributed to the writing of the manuscripts.

Amusa, F.L.: Contributed to the writing of the manuscript and designated to the research.

Olasupo, A.D.: Designed the research plan, organized the study and contributed to the mouse work.

Olagoke, O.V.: Organized the study and coordinated the mouse work.

Awodiran, T.P.: Contributed to the mouse work.

\section{Ethics}

This article is original and contains unpublished material. The corresponding author confirms that all of the other authors have read and approved the manuscript and no ethical issues involved.

\section{References}

Andrad S.A., M.F. Abreu and A.P. Silveira, 2004. Influence of lead additions on arbuscular mycorrhiza and rhizobium symbioses under soybean plants. Applied Soil Ecol., 2: 151-156.

Augé, R.M., 2001. Water relations, drought and vesicular mycorrhizal symbiosis. Mycorrhiza, 11: 3-42.

Awotoye, O.O., M.B. Adewole and E. Dada, 2013. Assessment of the phytoremediation potentials of selected West African weeds in cadmium and lead contaminated soil. J. Sci. Res.

Awotoye, O.O., M.B. Adewole and O. Olofinjana, 2012. Assessment of Solenostemon monostachyus for phytoremediation potential under the influence of mycorrhizal inoculation in heavy metal pouted soil. J. S. Res.

Enkhtuya, B., J. Rydlová and M. Vosátka, 2002. Effectiveness of indigenous and non-Indigenous Isolates of arbuscular mycorrhizal Fungi in soils from degraded ecosystems and man-made habitats. Applied Soil Ecol., 14: 201-211. 
Fewtrell, L, R. Kaufmann and A. Prüss-Üstün, 2003. Lead: Assessing the environmental burden of disease at national and local levels. Geneva, World Health Organization Environmental Burden of Disease Series, No. 2.

Giuffré, L., R.I. Romaniuk, L. Marbán, R.P. Ríos and T. P. García Torres, 2012. Public health and heavy metals in urban and periurban horticulture. Emir. J. Food Agric., 24: 148-154.

Kamnev, A.A., 2003. Phytoremediation of Heavy Metals: An Overview. In: Recent Advances in Marine Biotechnology, Fingerman, M. and R. Nagabhushanam (Eds.), Science Publishers Inc., Enfield (NH), Bioremediation. USA, pp: 269-317.

Krämer, K., 2010. Metal hyperaccumulation in plants, annual revolutional. Plant Biol. Palo Alto, 61: 517-534.

Malcova, R., M. Vosatka and M. Gryndle, 2003. Effects of inoculation with Glomus intraradices on lead uptake by Zea mays L. and Agrotis capillaries L. Applied Soil Ecol., 239: 55- 67.
Olarenwaju, O.E., M.T. Adetunji, C.O. Adeofun and I.M. Adekunle, 2009. Nitrate and phosphate loss from agricultural land: Implication for non-point pollution. J. Nutrient Cycle Agroeco. Syst.

Rillig, M.C. and P.D. Steinberg, 2002. Glomalin production by an arbuscular mycorrhizal fungus: A mechanism of habitat modification. Soil Biol. Biochem., 34: 1371-1374.

Saba, H., P. Jyoti and S. Neha, 2013. Mycorrhiza and phytochelators as remedy in heavy metal contaminated land remediation. Int. Resources J. Environ. Sci., 2: 74-78.

Smith, S.E. and D.J. Read, 1997. Mycorrhizal symbiosis, academic press, San Diego, USA. phytoremediationa novel and promising approach for environmental clean-up. Biotechnology, 24: 97-124. 